DOI:10.36340/2071-6818-2020-16-3-10-20

The journal traditionally opens with an academic interview. In this issue, we present Vasily Tsereteli - Executive Director of the Moscow Museum of Modern Art, a Commissioner of the Ministry of Culture of the Russian Federation at International Exhibitions in Venice, Vice President of the Russian Academy of Arts, member of the Presidium of International Council of Museums, artist, photographer, who kindly agreed to answer questions from Maria Burganova, the Editor in chief of The Burganov House. The Space of Culture journal.

Spring and summer of 2020 were not easy all over the world due to the COVID-19 pandemic, which has affected the cultural space, the museum community, and artists. In these challenging conditions, the Moscow Museum of Modern Art has managed to find new forms of interaction between art and the viewer. 


\section{INTERVIEW WITH THE EXECUTIVE DIRECTOR OF THE MOSCOW MUSEUM OF MODERN ART, VICE PRESIDENT OF THE RUSSIAN ACADEMY OF ARTS, VASILY TSERETELI}

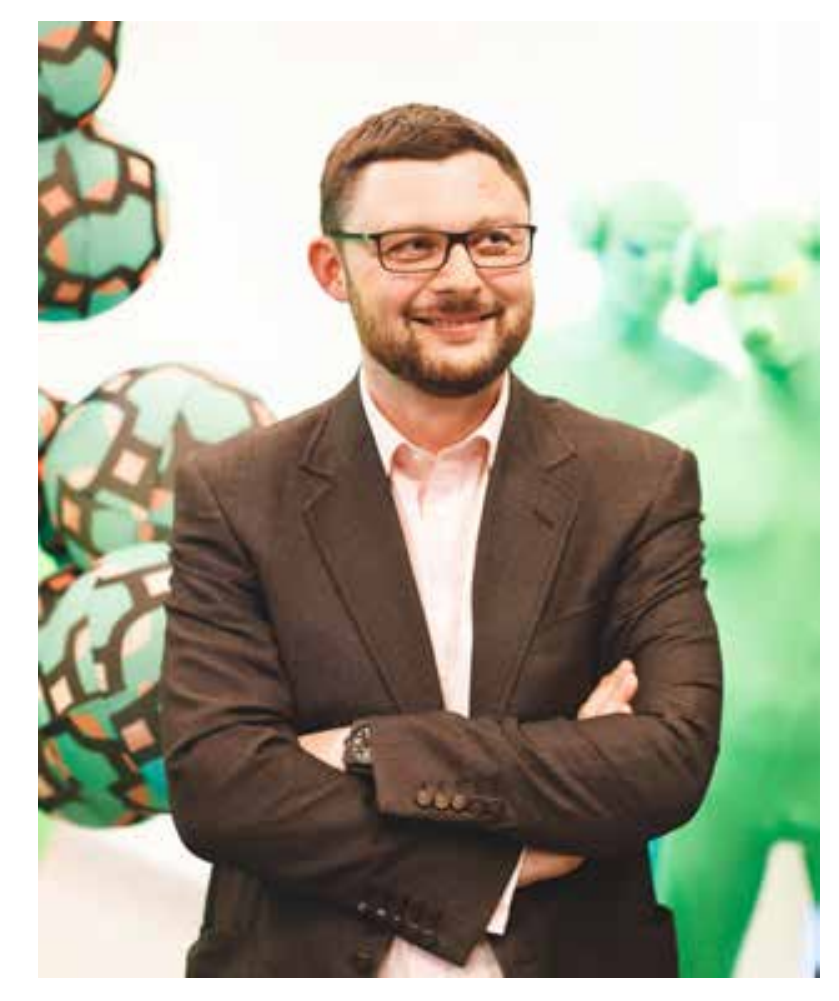

Vasili Z. Tsereteli

Maria A. Burganova: MMOMA is one of the symbols of the successful integration of Russian art into the world"s cultural space. Also, it is a platform for the presentation of prominent international cultural figures in Russia. How synchronous are the processes in culture and art in Russia and the world?

Vasili Z. Tsereteli: MMOMA is one of the symbols of the successful integration of Russian culture. The Moscow Museum of Modern Art is celebrating its $20^{\text {th }}$ anniversary this year, which is a significant event. MMOMA is the first state museum of contemporary art in modern Russia, which opened its doors in December 1999. The museum was created by artist Zurab Tsereteli, whose central concept was the art of the $20^{\text {th }}$ and $21^{\text {st }}$ centuries. As you know, Russia was the first country in which a museum of modern art was opened in 1923. Shchukin and Morozov were among the first to open the heritage of world culture to the public. Russia has always been ahead in the Avant-garde and many other areas of art. The Moscow Museum of Modern Art, like many other international museums, ranks equally in concept and direction, like the Pompidou Center in France, the New York Museum of Modern Art, and Tate Modern in London. For all of them, preserving the heritage of the previous generations, studying, and transmitting the modern heritage to future generations is crucial.

M.B.: How can you characterize the potential audience of the museum? How much does it change?

V.Ts: The audience of the museum is very extensive. We see, especially now, that families with children, young people start to attend... Basically, of course, people aged 25 to 55 are the primary audience; however, there are also many young people 


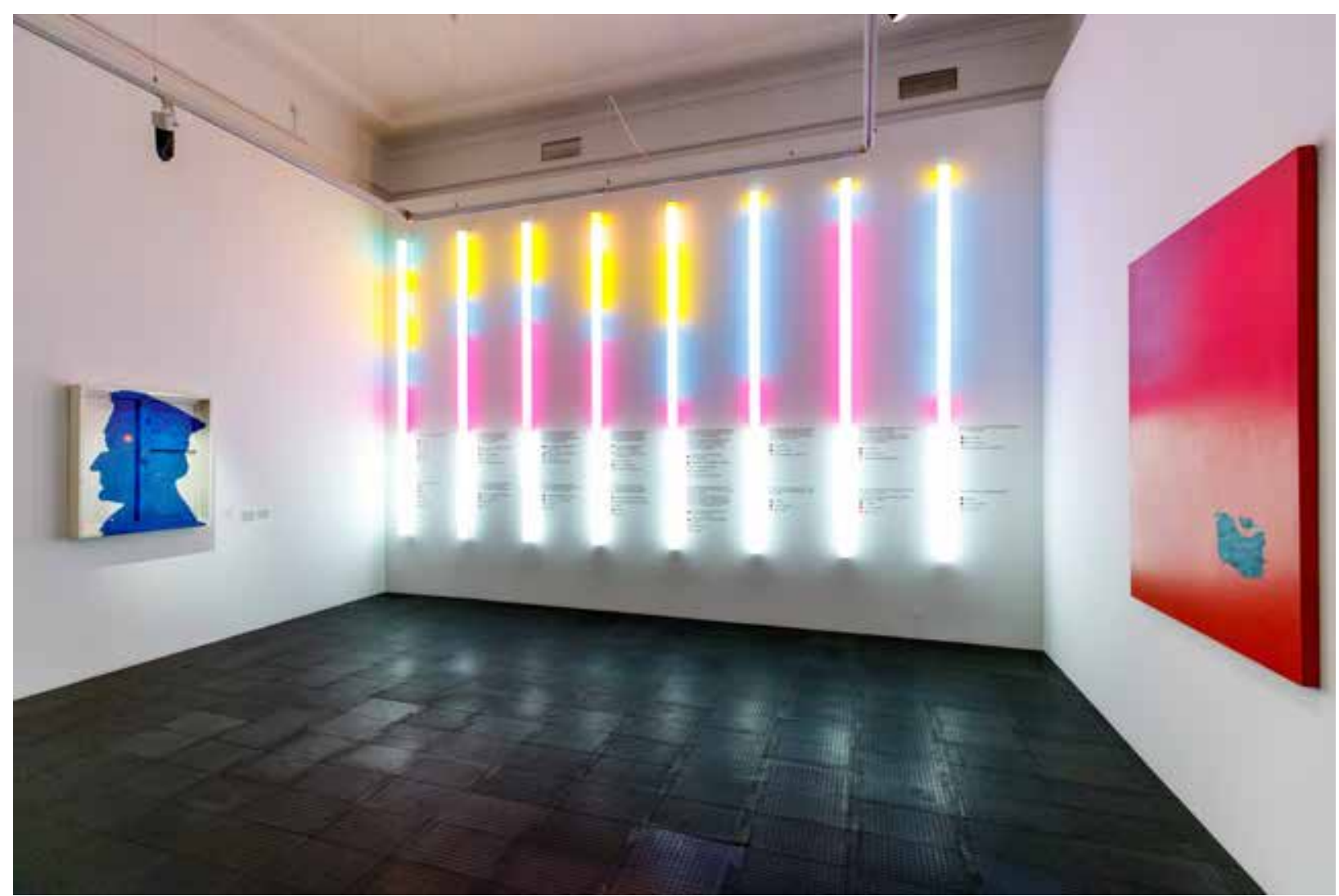

Exposition Moscow Museum of Modern Art. Moscow. Photo by Sergi Shagulashvili

and older people among the museum"s visitors. As you know, the museum has six different venues. For each of them, various programs, special excursions, visits have been developed. We try to make the museum accessible to everyone. Everyone must find their place in the museum. Of course, now that everyone is in quarantine, we see high attendance in our online programs. The museum has made a great emphasis on posting excursions online and thus striving to keep the number of audiences not decreasing but, on the contrary, increasing. The Night of Museums showed that interest in the Museum did not diminish but remained practically at the same level as during regular times when people attended the Night of Museums.

M.B.: New formats emerged in art in the $20^{\text {th }}$ century. However, taking into account globalization, virtuality, new technologies - what is your projection of art development in the $21^{\text {st }}$ century?

V.Ts: Yes, we can see how much everything is being transferred online and made digital, especially now during this pandemic, when all people have been isolated for three months. It can be said that the study of art, the observation of art and artists through the Internet began to prevail. I believe that this trend will only continue to grow. Many artists are already creating works in a virtual space, particularly in a virtual one with glasses, through which one can observe sculptures and paintings. Museums produce exhibitions in virtual space. At the same time, before transferring art to the virtual space, sculptors initially create their works with their hands, and artists make sketches. Therefore, the art that is and will be created by sculptors, painters, photographers will still be exhibited and will continue to exist in museums. I think that art in the virtual space will continue to develop but in parallel, while preserving the museum space.

M.B.: Can a museum influence the national idea through art, creative projects, educational programs? Do you think that MMOMA is responsible to society and the state?

V.Ts: I think that, of course, each museum has its responsibility in the sense that it shows history: artistic history, history of culture, society, history of a place. When we visit the Pompidou Center 


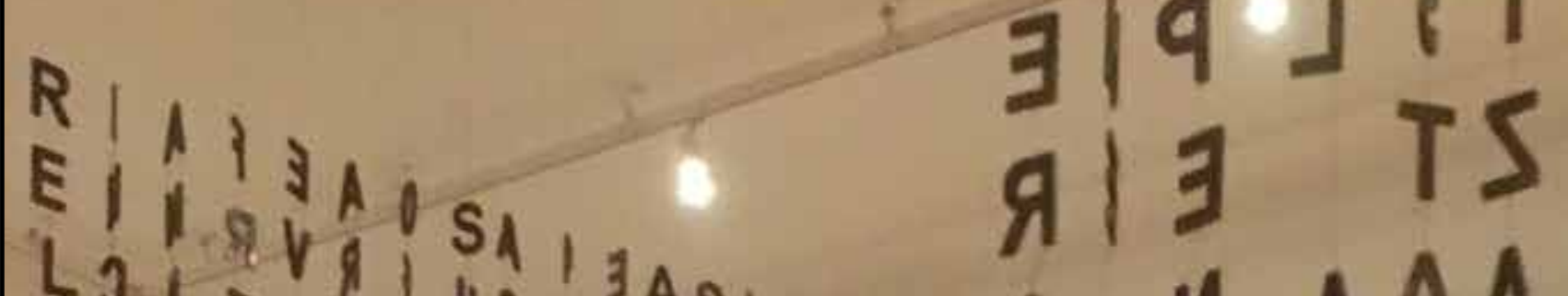

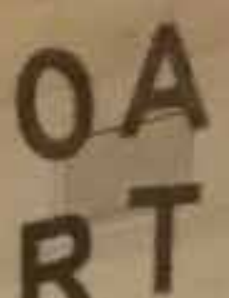

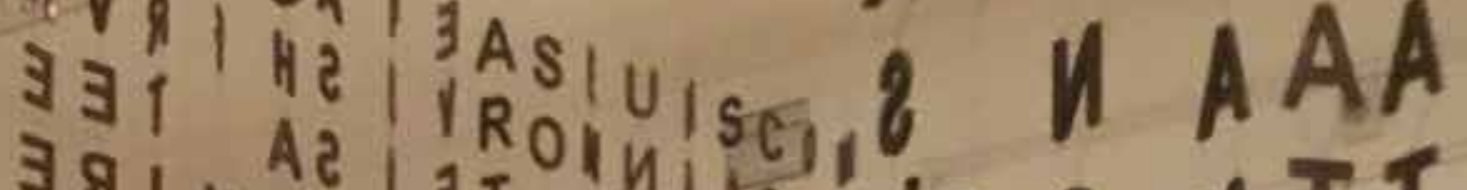

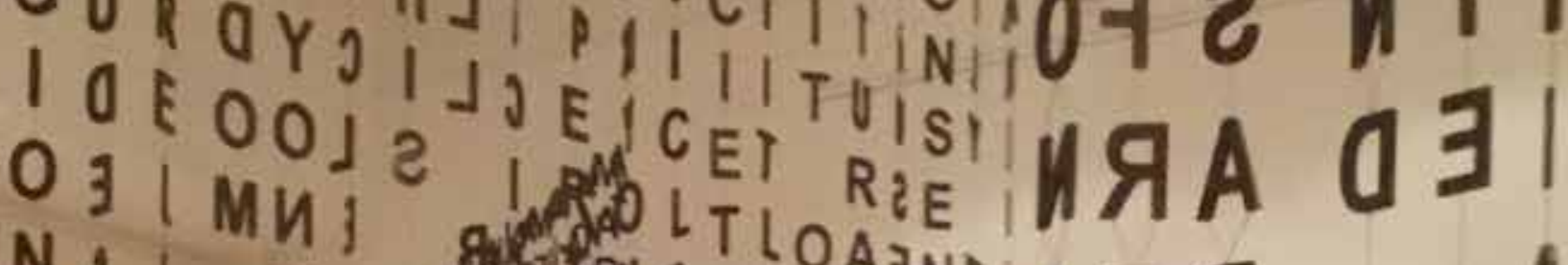

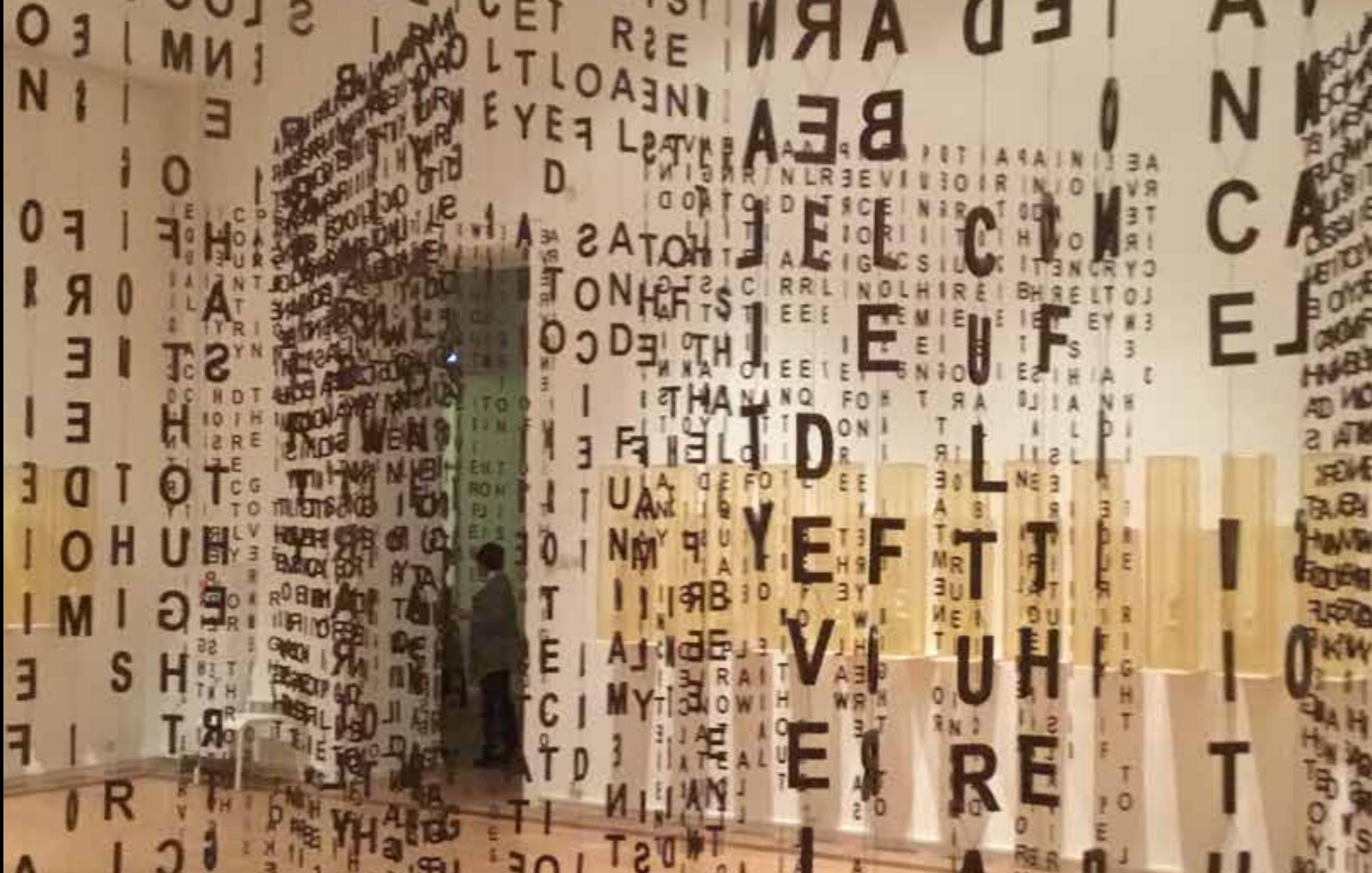

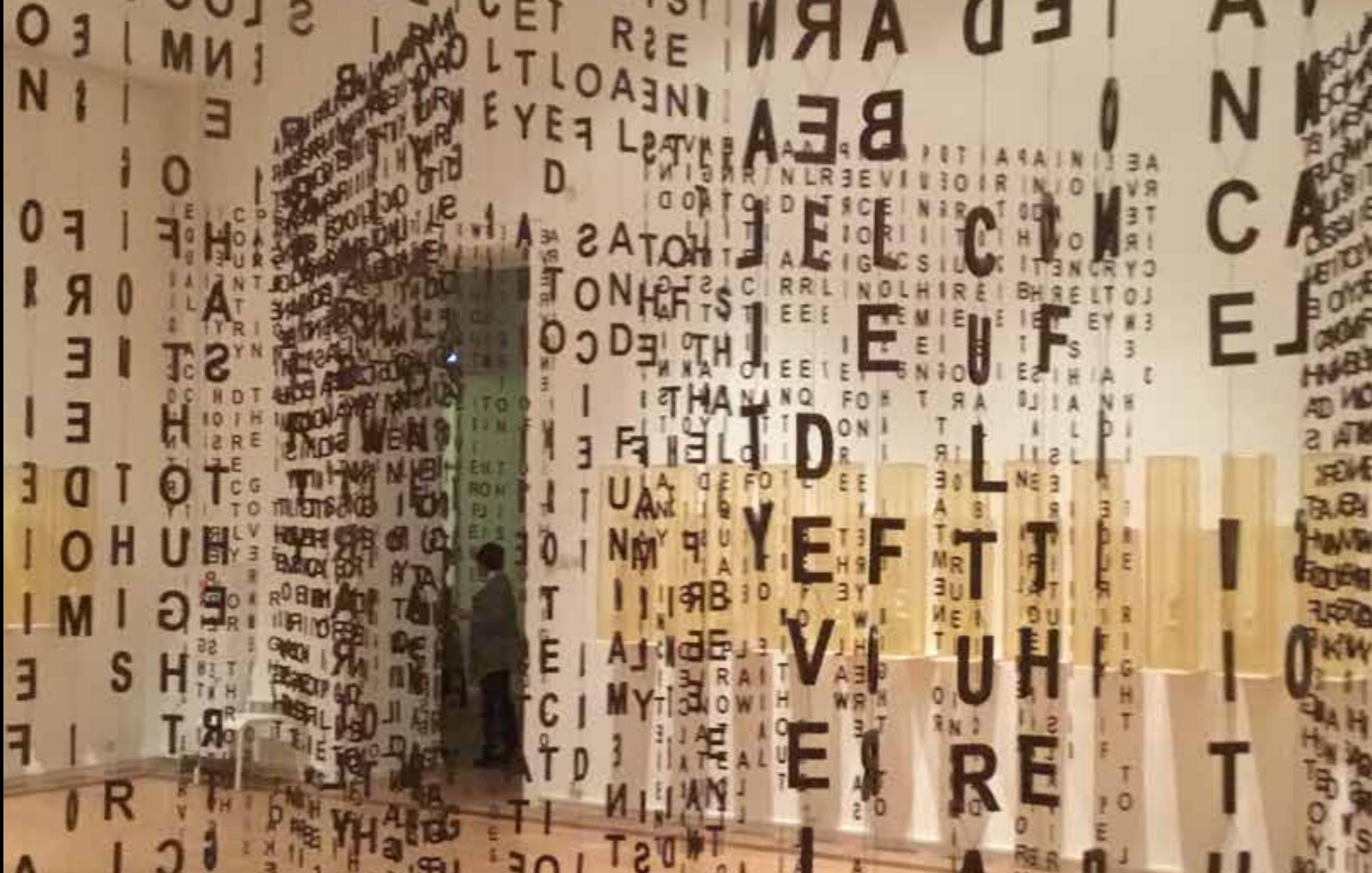

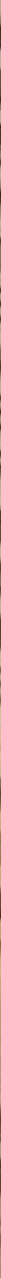

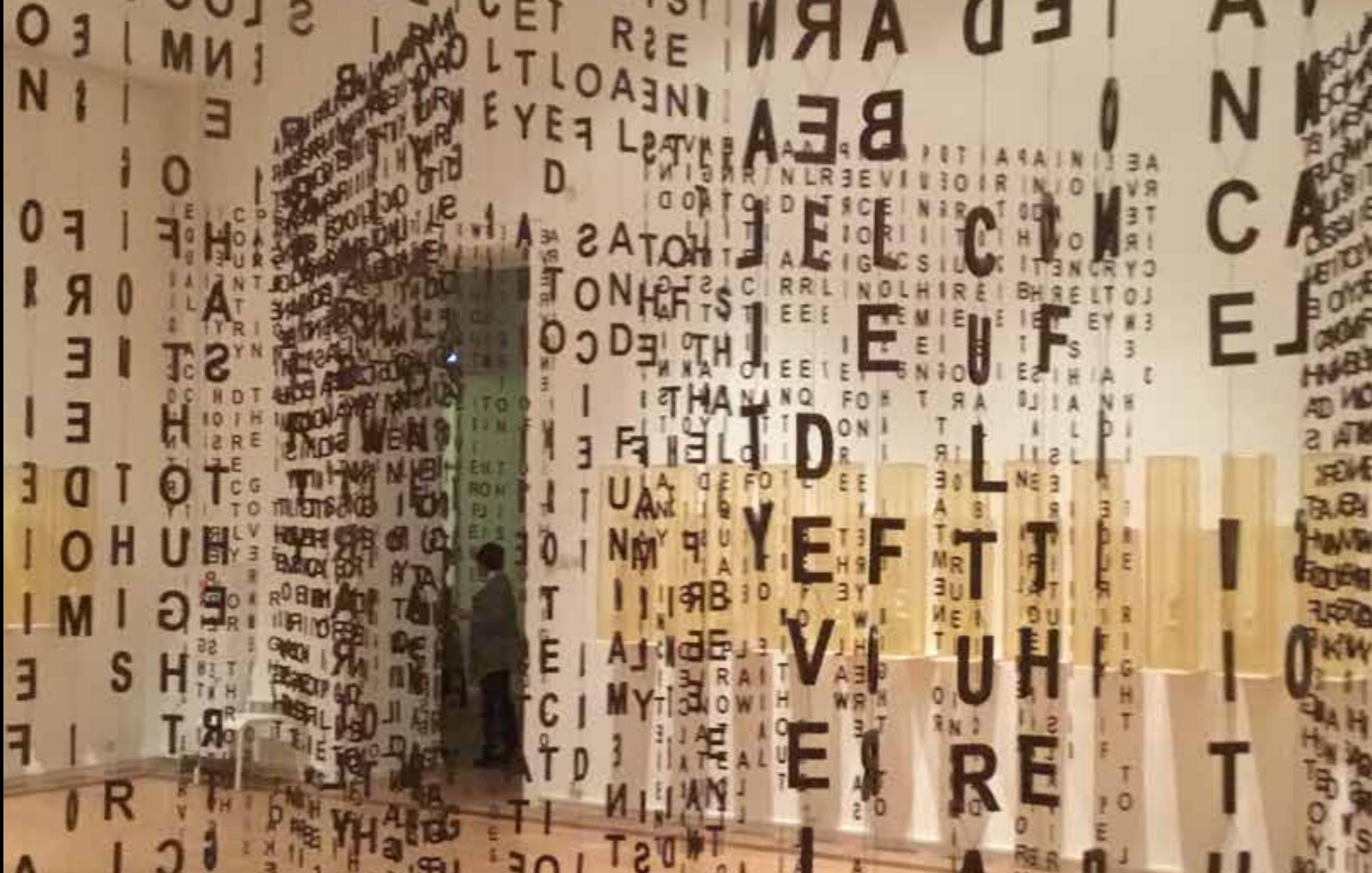

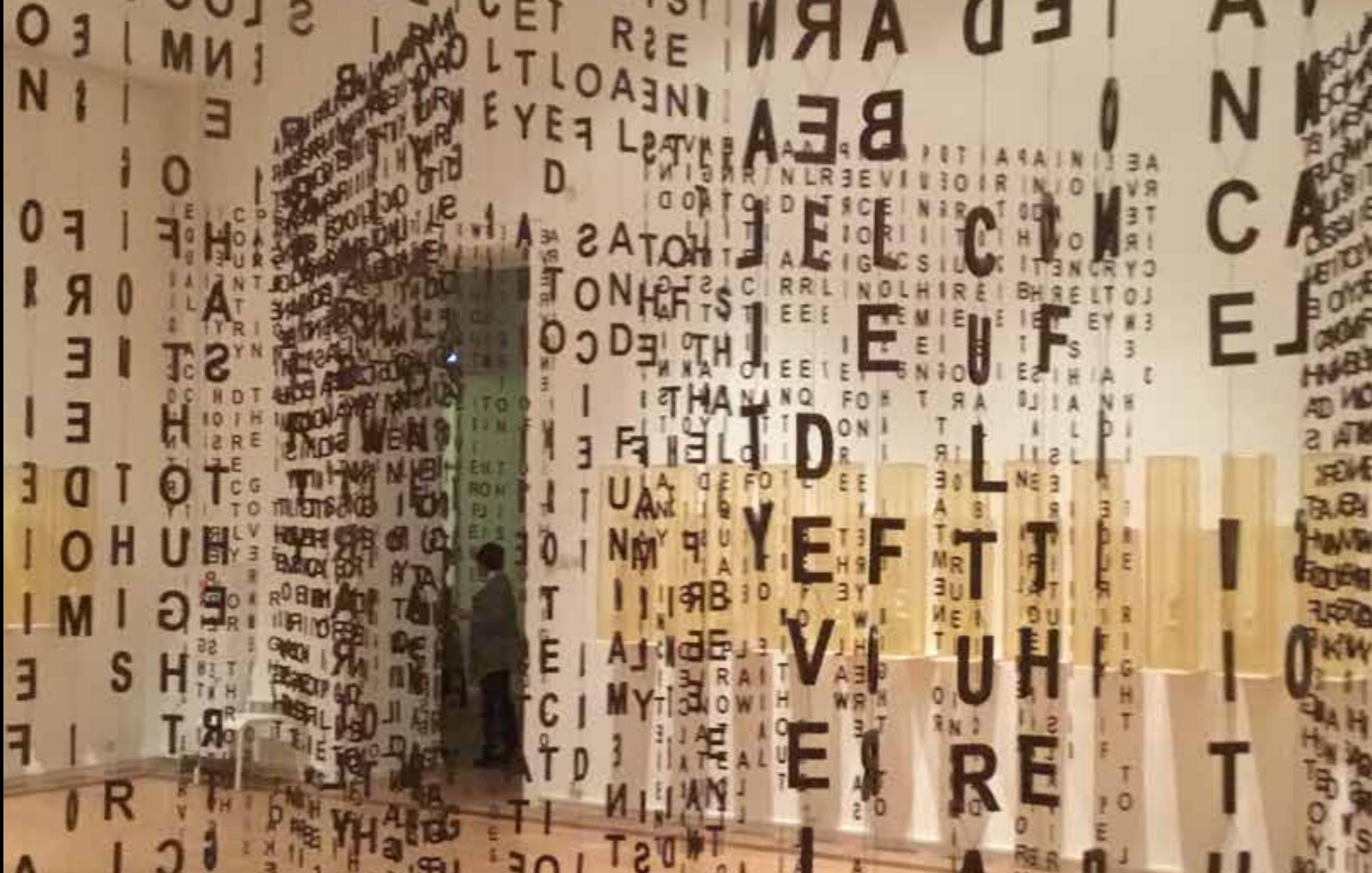

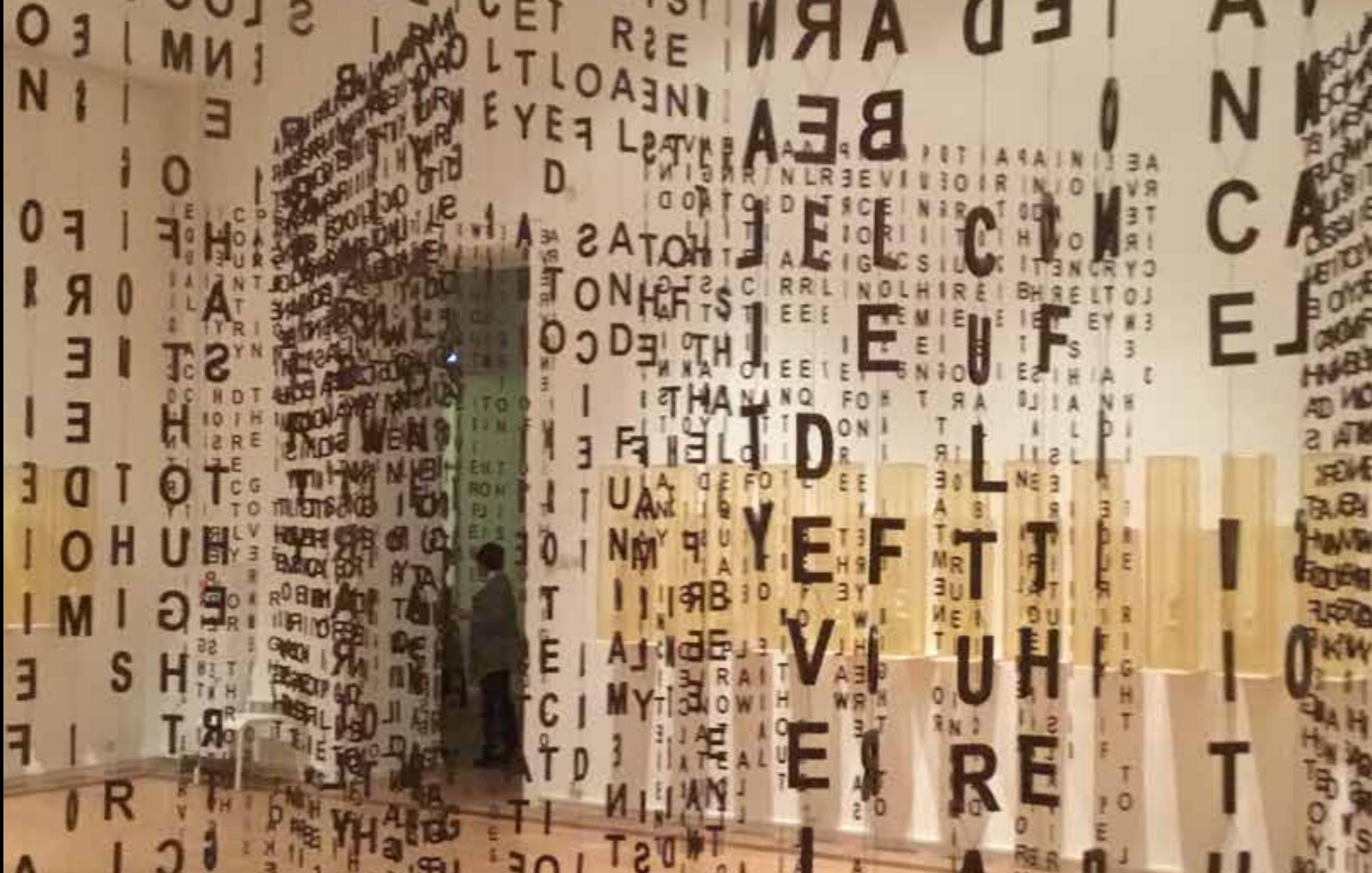

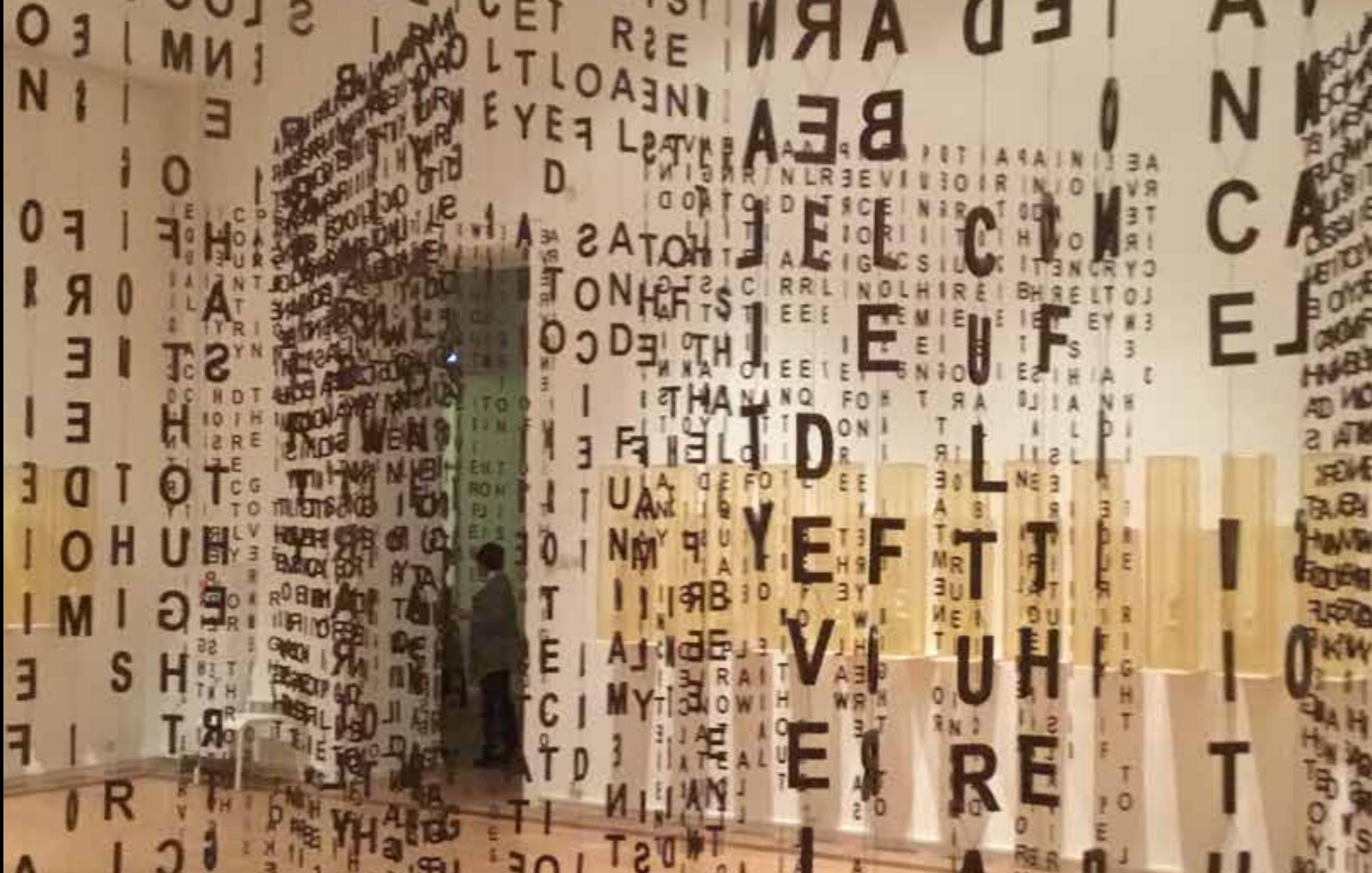

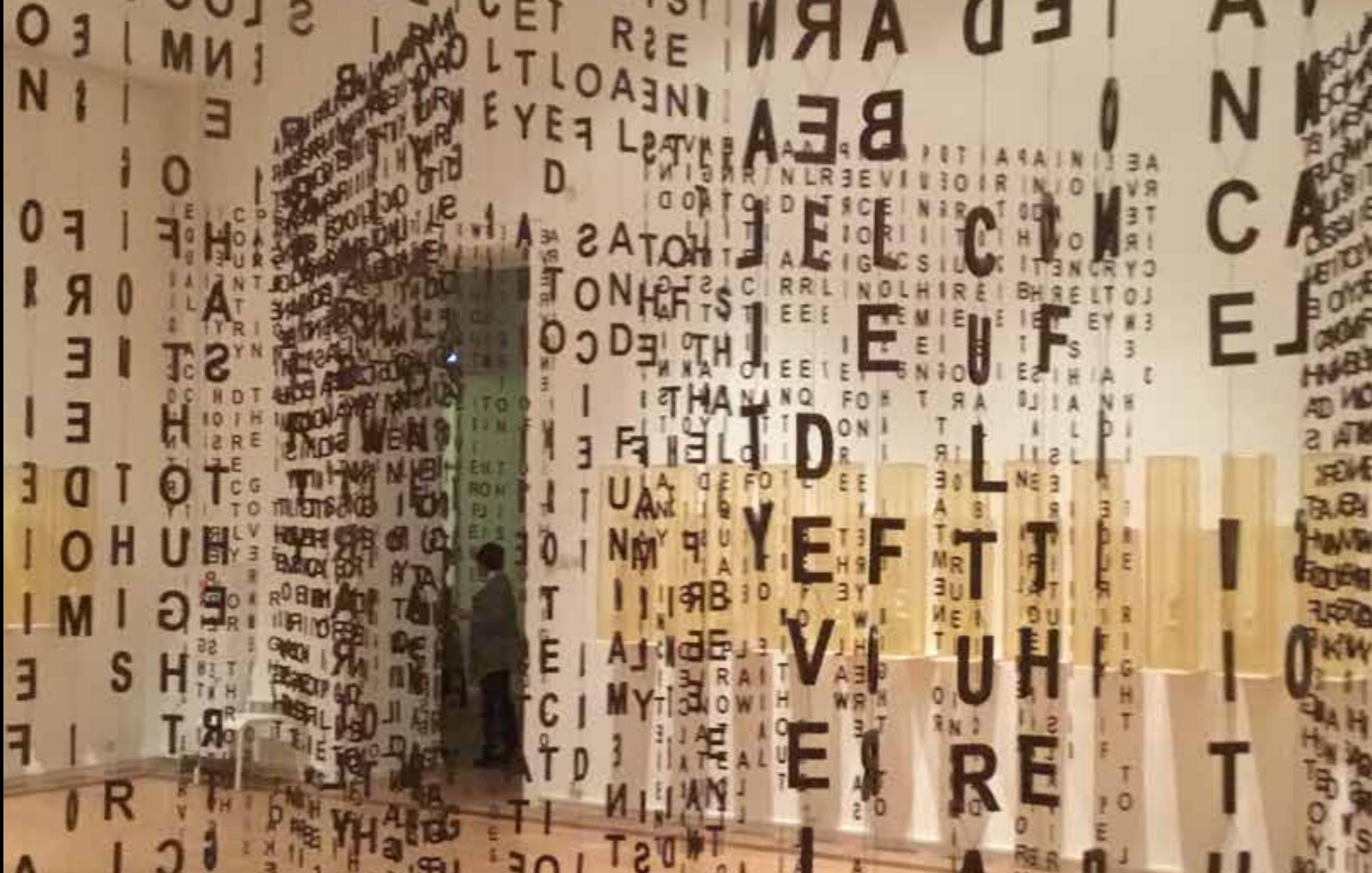

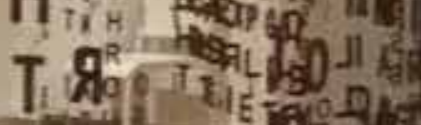

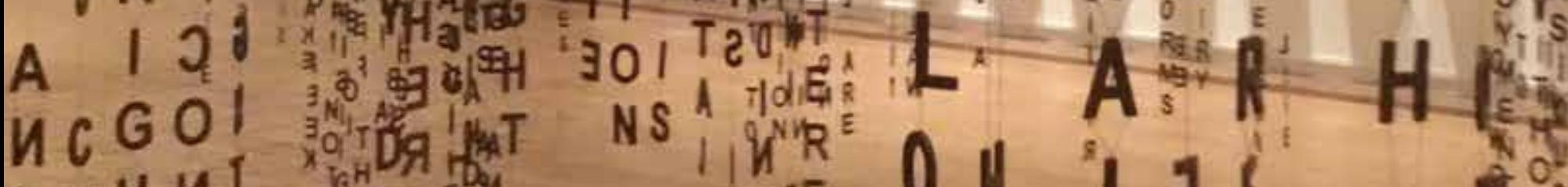
OHH ИT
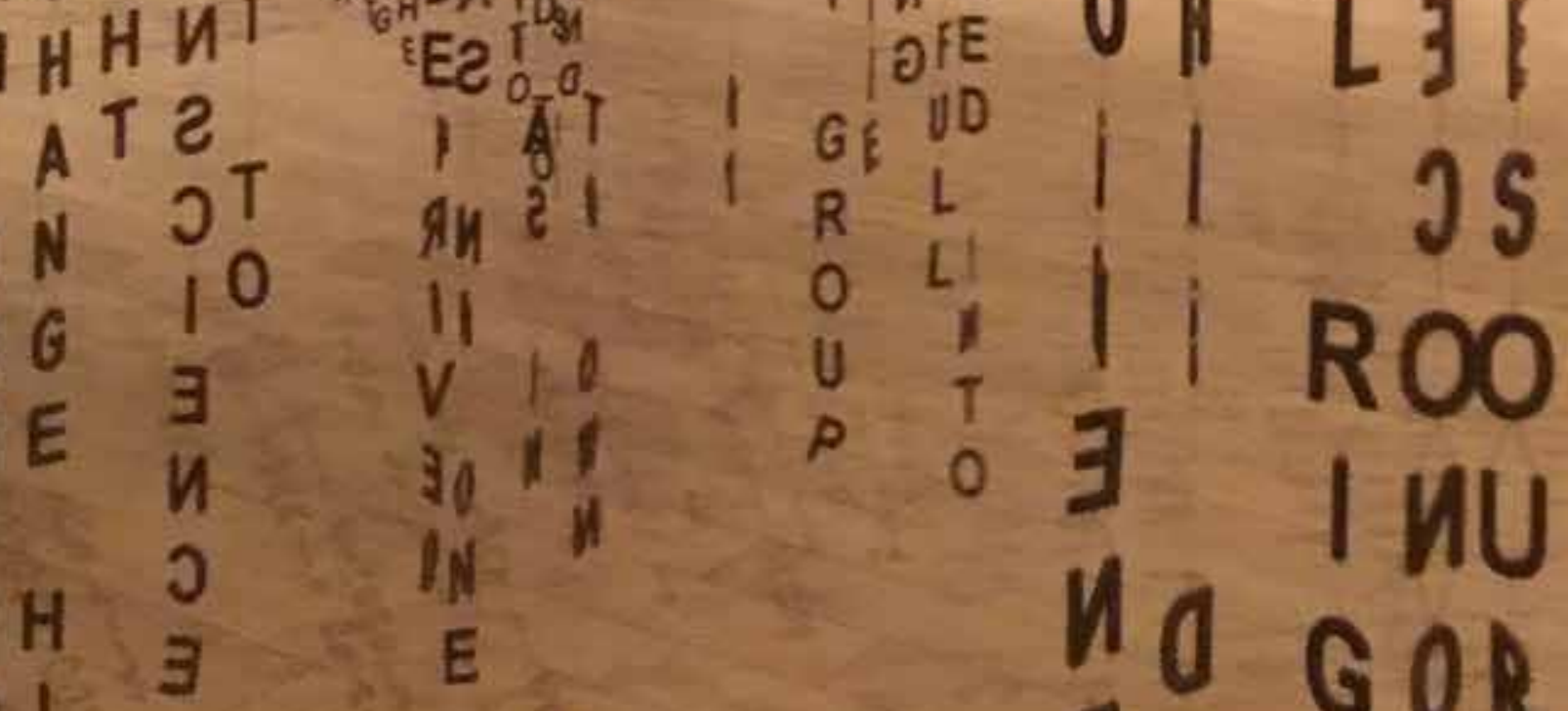

i. $\mathrm{U}^{\mathrm{A}}$ 


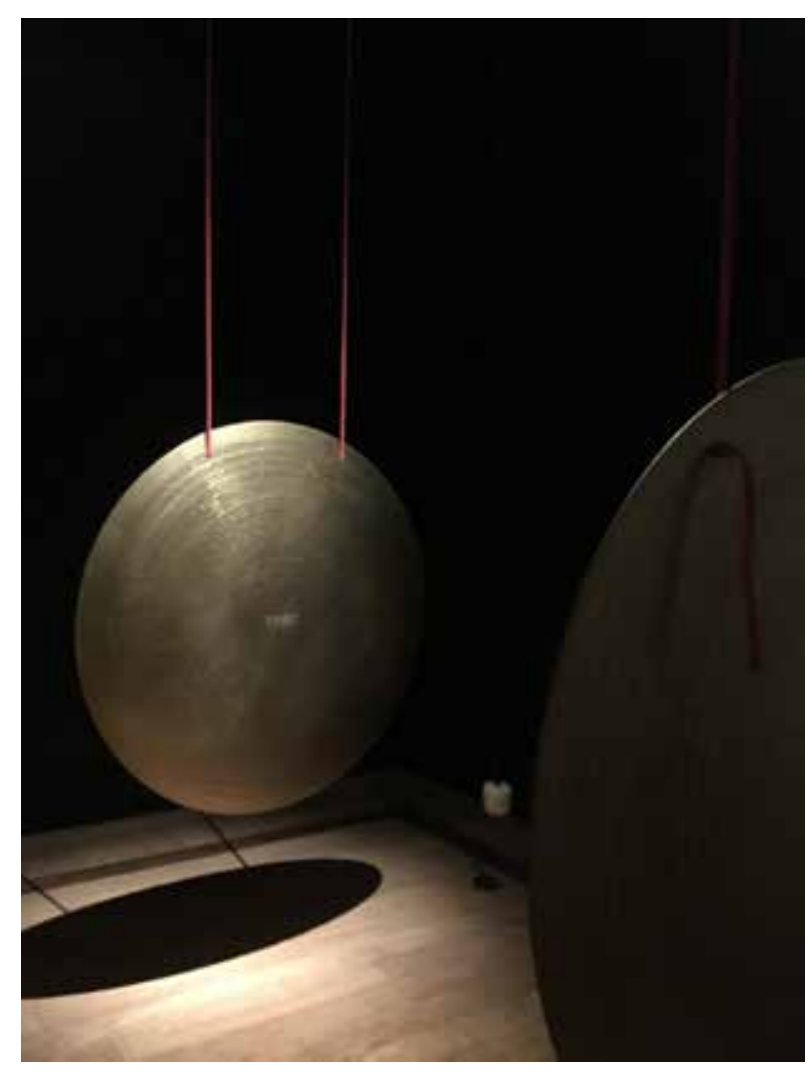

Exposition Jaume Plensa. 2019. MMOMA. Moscow. Photo by Maria Burganova

in France, we see how the French perceive the history of the $20^{\text {th }}$ and $21^{\text {st }}$ centuries through the prism of their perception. Including their understanding of world culture. Russian art is also represented in Pompidou, but again it is presented through their vision. When we come to America, this is the view of the American curatorship and specialists on world history, that is, the view of the English-speaking world. When you visit a museum in Russia, it is certainly a look at art through our prism, our perception. And so it should be. When you visit museums in different countries, you realize that it is impossible to copy them. Of course, in this sense, every museum, every scientific department of the museum works to educate, show and explain art in that context, in that historical prism, in that time, both the past and the present, with analysis and in time development.

M.B.: What are the criteria for a new format of art, devoid of real museum space and genuine works? After all, one has to perceive a virtual product as a museum object, as a masterpiece.

V.Ts: Distance is needed for the perception of any art, work. Very often, it takes time to

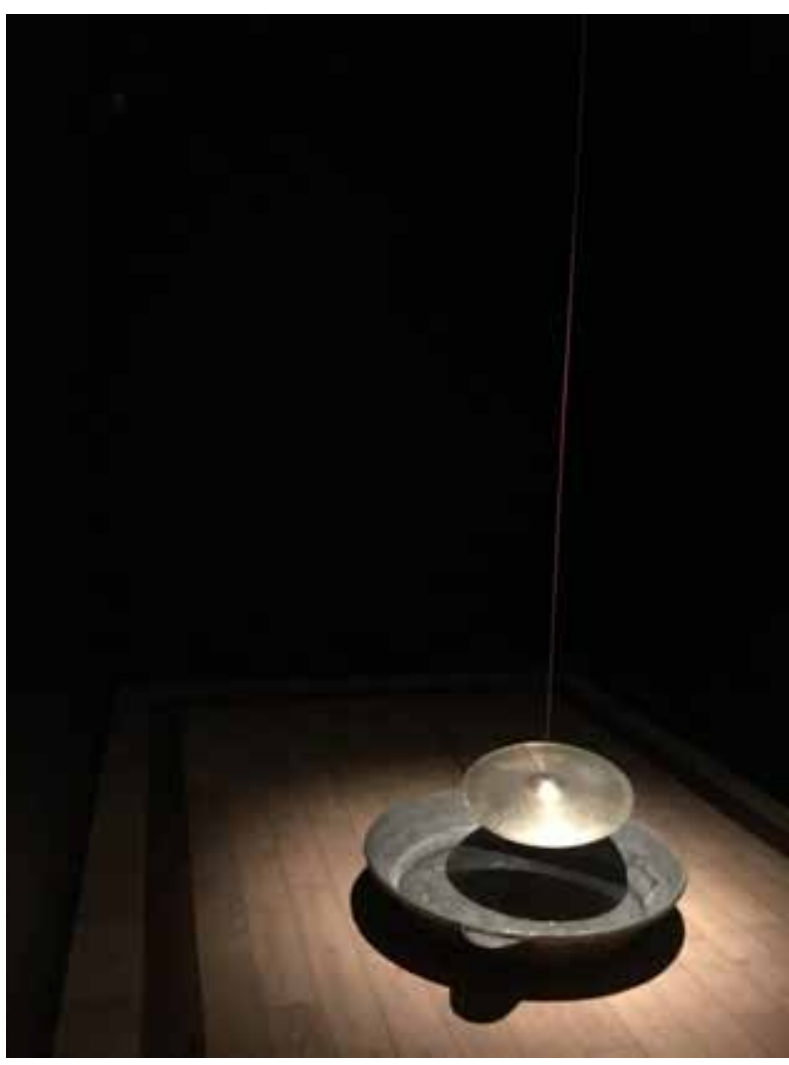

Exposition Jaume Plensa. 2019. MMOMA. Moscow. Photo by Maria Burganova

determine what is a museum quality piece and what is not. The art that we know and that is modern is diverse: from realistic to abstract, virtual, to virtual realism, to graphic, to games, and so on. A vast number of different art formats exist. Depending on the created, the works are further evaluated by experts and eventually end up in a museum. Therefore, it takes time to test which works of art will remain in cultural memory and which will not.

M.B.: Will the new generation, accustomed to living in the virtual world, need a real museum? Wouldn't it have the fate of an inaccessible bank safe into which only specialists can enter? Will the museum survive as a bridge between the real work of art and the viewer?

V.Ts: A museum is always more than just a depository of art. It is essential to understand that a museum is an institution - a scientific institution that studies, explores, shows, demonstrates, educates, and enables people to immerse themselves in intellectual progress. Thus, a person develops at all levels: from visual and tactile to all other types of perception. 


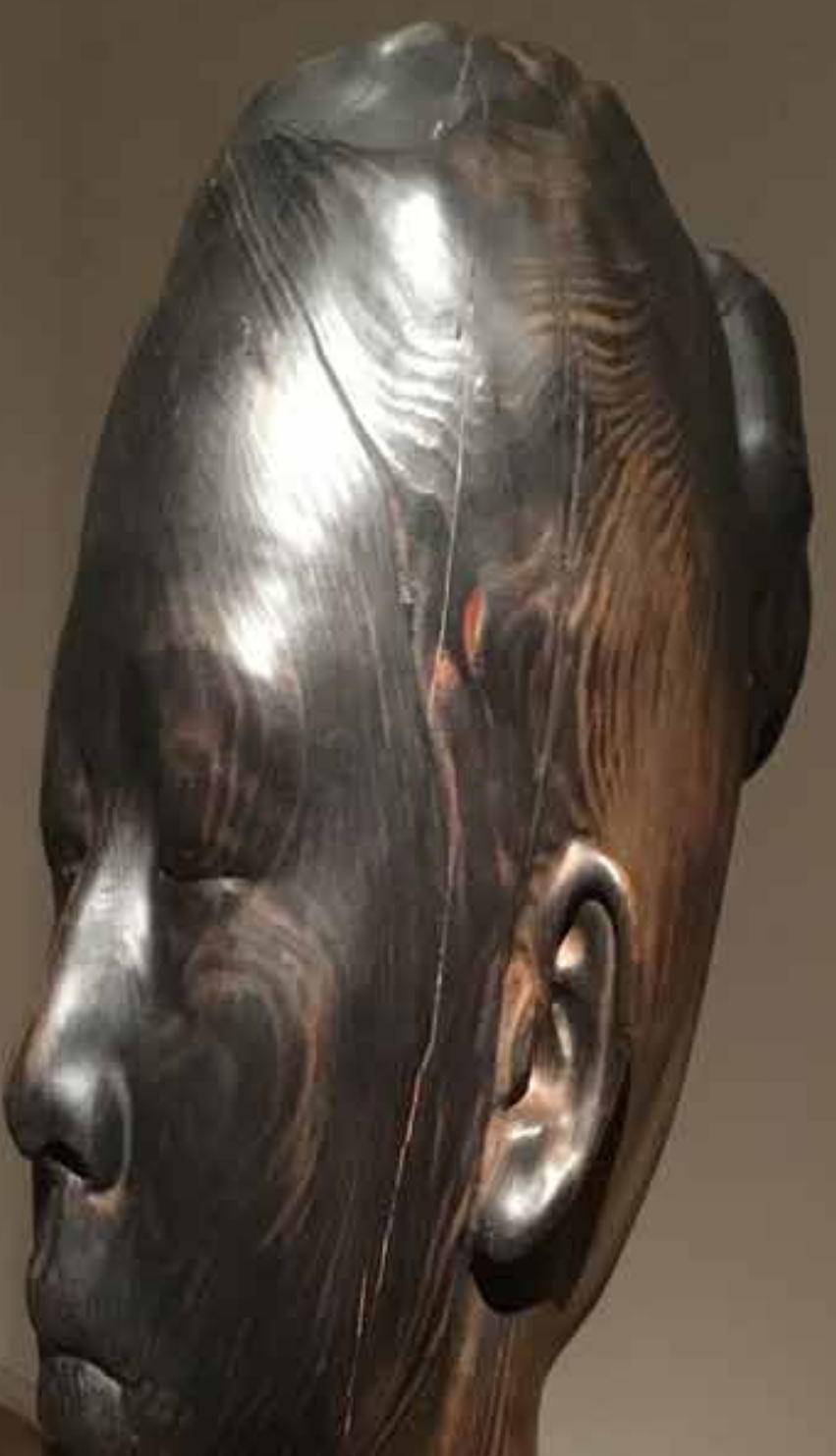

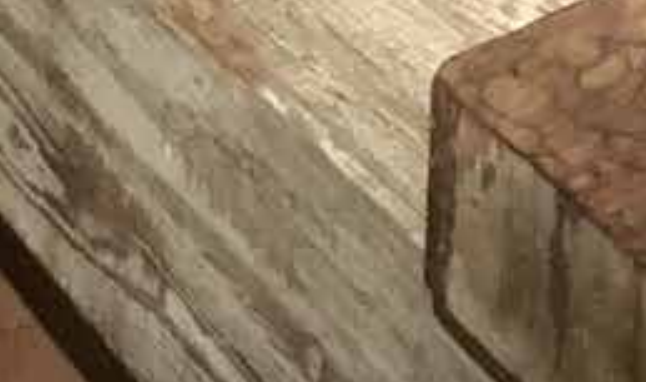

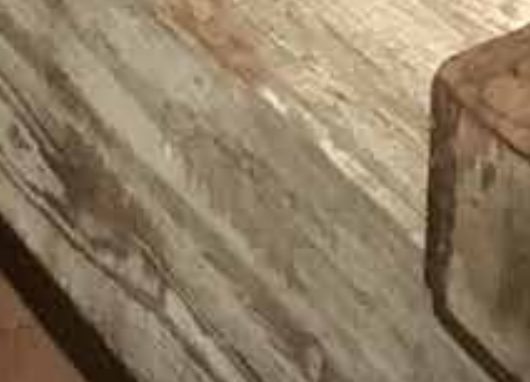

m M. it 
Any virtual world provides only a platform, again, in virtual space. There are various works of art, especially those that need to convey sound, smell, spatial perception, scale, human relationship (especially for sculpture, where there are two objects - you, as a viewer, is the first object, and sculpture is the second one). This dynamism between you and the object you are looking at requires a different perception. Therefore, in any case, museums will always exist. It was discussed many times in the history of art. We saw in the 60 s in world art, in America and other countries, when artists were against museums, against the museification of art, and tried to create works that could not be museumified. However, in the end, all these works were preserved and continued to be created further. This is how the market works; this is how space is arranged. There are whole areas, such as food art, the works of which are still museumified, studied, and preserved.

Thus, I think the role of museums will only grow stronger. The museums will use the virtual aspects as some opportunities for deepening, for the possibility to convey the idea of exhibitions, projects, collections the museum has to the world audience with the help of the Internet and virtual space. It would be possible for the museum to go beyond the city as well as convey, show in high quality to those citizens of the country who do not have the opportunity, for example, to come to Moscow to see projects, exhibitions every month or visit museums several times a year. Hence, they can see it all online.

Therefore, this is a significant work carried out by museums as scientific, cultural, and research centers: vast archives, presentations to libraries, and the creation of scientific capital. For any country, for any society, it is crucial to have museums and scientific centers that preserve the culture of the state in which we live. Science, art, and culture are the foundation of any society. Thus, it is vital for art to be preserved, explored, and displayed in its original context without manipulation, documenting everything reasonably for future generations. 


\section{DOI:10.36340/2071-6818-2020-16-3-10-20}

Традиционно наш журнал открывает академическое интервью. В этом номере мы представляем Василия Церетели - исполнительного директора Московского музея современного искусства, комиссара Министерства культуры Российской Федерации на Международных выставках в Венеции, вице-президента Российской академии художеств, члена президиума ИКОМ, художника, фотографа, который любезно согласился ответить на вопросы главного редактора журнала «Дом Бурганова. Пространство культуры» Марии Александровны Бургановой.

Весна и лето 2020 года были не простыми во всем мире, в связи с пандемией COVID-19, что отразилось на пространстве культуры, музейном сообществе, художниках. В этих сложных условия Московский музей современного искусства сумел найти новые формы взаимодействия искусства и зрителя. 


\section{ИНТЕРВЬЮ С ИСПОЛНИТЕЛЬНЫМ ДИРЕКТОРОМ МОСКОВСКОГО МУЗЕЯ СОВРЕМЕННОГО ИСКУССТВА, ВИЦЕ-ПРЕЗИДЕНТОМ РОССИЙСКОЙ АКАДЕМИИ ХУДОЖЕСТВ ВАСИЛИЕМ ЗУРАБОВИЧЕМ ЦЕРЕТЕЛИ}

Мария А. Бурганова: ММОМА - один из символов успешной интеграции отечественного искусства в мировое культурное пространство и площадка представления выдающихся международных деятелей культуры в России. Насколько синхронны процессы в культуре и искусстве в России и в мире?

Василий 3. Церетели: ММОМА - действительно один из символов успешной интеграции отечественной культуры. Московский музей современного искусства в этом году празднует свой юбилей, двадцатилетие, и это очень важное событие. ММОМА является первым в современной России государственным музеем современного искусства, который открыл свои двери в декабре 1999 года. Музей создан художником Зурабом Церетели, у которого главной концепцией было искусство XX-ого и XXI-ого веков. Как известно, Россия была первой страной, в которой открылся музей современного искусства в 1923 году. Щукин и Морозов были одними из первых в мире, кто открыл достояние мировой культуры для публики. Россия всегда была впереди по авангарду и по многим другим направлениям искусства. Московский музей современного искусства так же, как и многие другие международные музеи, стоит в одном ряду по концепции и по направлению с такими известными музеями, как Центр Помпиду во Франции, Музей современного искусства НьюЙорка, Tate Modern в Лондоне. Для них всех важным является сохранение наследия предыдущего поколения, изучение и передача современного наследия будущим поколениям.

М.Б.: Как можно охарактеризовать потенциальную аудиторию музея? Насколько она меняется?

В.Ц.: Аудитория музея очень обширна. Мы видим, особенно сейчас, появление семей с детьми, молодых людей... Конечно, основная аудитория - это люди в возрасте от 25 до 55 лет, но также среди посетителей музея очень много молодёжи и людей старшего возраста. Как известно, у музея есть шесть разных площадок, под каждую из которых разработаны разные программы, специальные экскурсии, посещения. Мы стараемся, чтобы музей был доступен для всех. Важно, чтобы каждый находил в музее своё место. Конечно, сейчас, когда все находятся на карантине, мы видим огромную посещаемость наших онлайн-программ. Музей сделал большой акцент на то, чтобы выкладывать экскурсии в онлайн-режиме, тем самым мы стремимся, чтобы аудитория не сокращалась, а, наоборот, увеличивалась. Ночь музеев показала, что интерес к Музею не упал, а остался практически на том же уровне, что и в обычное время.

М.Б.: В ХХ веке возникли новые форматы в художественном творчестве, и, учитывая глобализацию, виртуальность, новые технологии, - каковы Ваши прогнозы развития искусства в XXI веке?

В.Ц.: Да, мы видим, особенно сейчас, во время этой пандемии, когда три месяца все люди находятся в изоляции, насколько всё больше и больше всего переходит в онлайн и цифровую среду. Можно сказать, что стало преобладать изучение искусства, наблюдение за искусством и художниками через Интернет. Я думаю, что эта тенденция будет только усиливаться и увеличиваться. Многие художники уже сейчас создают работы в виртуальном пространстве, в частности, когда через очки виртуальной реальности можно наблюдать за скульптурами и картинами. Музеи создают экспозиции в виртуальном пространстве. Но при этом, перед переводом искусства в виртуальное пространство, первоначально работы создаются руками скульпторов, делаются эскизы художниками. Поэтому искусство, которое создаётся и будет создаваться скульпторами, живописцами, фотографами, всё равно будет выставляться и будет продолжать существовать в музеях. Я думаю, что искусство в виртуальном пространстве и дальше будет развиваться, но параллельно, при сохранении музейного пространства.

М.Б.: Может ли музей влиять средствами искусства, творческими проектами, образовательными программами на национальную идею? Вы считаете, что ММОМА несёт ответственность перед обществом и государством?

В.Ц.: Думаю, что, безусловно, каждый музей несёт свою ответственность. В том смысле, что 
показывает историю: художественную историю, историю культуры, общества, историю того или иного места. Когда мы во Франции посещаем Центр Помпиду, то видим, как французы воспринимают историю XX и XXI века через призму своего восприятия. В том числе, их восприятие мировой культуры. В Помпиду представлено и российское искусство, но, опять же, оно подается через их видение. Когда мы приезжаем в Америку, то это взгляд американского кураторства и специалистов на мировую историю, то есть взгляд англоязычного мира. Когда вы приходите в музей в России, то это, безусловно, взгляд на искусство через нашу призму, наше восприятие. И так и должно быть. Когда ты посещаешь музеи в разных странах, то понимаешь, что невозможно их скопировать. Безусловно, в этом смысле каждый музей, каждый научный отдел музея работает над тем, чтобы образовывать, показывать и «рассказывать» искусство в том контексте, в той исторической призме, в том времени, как прошлом, так и сегодняшнем, с анализом и во временном развитии, которые будут близки и понятны современному человеку - зрителю, посетителю музея.

М.Б.: Каковы критерии нового формата искусства, лишённого реального музейного пространства и подлинных произведений? Ведь виртуальный продукт нужно суметь воспринимать как музейный объект, как шедевр.

В.Ц.: Для восприятия любого искусства, произведения нужна дистанция, очень часто нужно время, чтобы определить, что является музейной ценностью, а что нет. То искусство, которое мы знаем и которое является современным, - разнообразно: от реалистического до абстрактного, виртуального, до виртуального реализма, до графического, до игры и так далее. Огромное количество разнообразных форматов искусства, и, в зависимости от созданного, произведения далее оцениваются экспертами и со временем оказываются в музее. Поэтому нужно время для апробирования: какие работы останутся в культурной памяти, а какие нет.

М.Б.: Будет ли нужен реальный музей новому поколению, привыкшему жить в виртуальном мире? Не уготована ли ему судьба недоступного банковского сейфа, в который вхожи только специалисты? Сохранится ли музей как мост между реальным произведением искусства и зрителем?

В.Ц.: Музей - это всегда больше, чем просто хранилище искусства. Важно понимать, что музей является институцией - научной институцией, которая изучает, исследует, показывает, демонстрирует, образовывает и дает возможность человеку погрузиться в интеллектуальный прогресс. Таким образом, человек развивается на всех уровнях: от визуально-тактильного до всех остальных видов восприятия.

Любой виртуальный мир даёт только площадку, опять же, виртуального пространства. Среди разнообразия произведений искусства есть те, которые нуждаются в передаче звука, запаха, пространственного восприятия, масштаба, соотношения человека (особенно это касается скульптуры, где есть два объекта: Вы как зритель - один объект, скульптура - другой объект). Вот эта динамика между тобой и тем объектом, на который смотришь, требует другого восприятия. Поэтому, в любом случае, музеи всегда будут существовать. Много раз обсуждалось в истории искусства, и мы видели в 60-е годы в мировом искусстве, в Америке и других странах, когда художники выступали против музеев, против музеефикации искусства и пытались создать работы, которые невозможно было музеефицировать. Но в итоге, все эти работы, произведения консервировались и далее продолжались создаваться, - так работает рынок, так устроено пространство. Есть целые направления, например, food art, произведения в стиле которых все равно музеефицируются, изучаются и сохраняются.

Поэтому, я думаю, роль музеев будет только укрепляться. Виртуальные аспекты музеи будут применять как некие возможности для углубления, для того, чтобы дать возможность с помощью Интернета и виртуального пространства донести идею выставок, проектов, коллекций, которые имеются у музея, до мирового зрителя, что даёт возможность музею выйти за рамки города, а также донести, показать в высоком качестве тем гражданам страны, которые не имеют возможности, к примеру, каждый месяц приезжать в Москву, смотреть проекты, выставки или несколько раз в год посещать музеи. А таким образом они могут всё это увидеть онлайн.

Поэтому это очень важная работа, которую ведут музеи как научные центры, центры культуры, исследования: огромные архивы, коллекционирование архивов, передача в библиотеки и создание научного капитала. Для любой страны, для любого общества очень важно иметь музеи, научные центры, которые сохраняют культуру той страны, в которой мы живём. Наука, искусство, культура это фундамент любого общества. Поэтому важно, чтобы искусство сохранялось, исследовалось и показывалось в исходном контексте без манипуляций, документально и корректно, до будущих поколений. 